\title{
AUGUSTIN VOLOSHYN AS A FORERUNNER OF PHILOSOPHIC AND PEDAGOGICAL THOUGHT AT THE EDGE OF EPOCHS
}

\author{
We are Ukrainian, \\ We are called Ukrainians, \\ And the land is Ukraine! \\ Because this land is the land of freedom, \\ Our people live on it! \\ In the native mountains there are native rivers, \\ Native song is floating here.
}

(V. Grenja-Donsky)

In the article the way of life of Augustine Voloshin has been reviewed, the teaching, scientific and organizational, publishing and political activity have been characterized, his philosophical and pedagogical concept has been analyzed. Philosophical thought, which seems to have now ceased, should prepare for a new universal cognitive desire to look at the horizons of the future and take on the mission of understanding and rethinking the national and universal (historical, political, social psychological, philosophical) pedagogical experience. In this context, Voloshin's philosophical and pedagogical heritage plays an important role as an outstanding Ukrainian thinker, humanist, educator. Remembering A. Voloshin's merits as a politician, a fighter for freedom and independence of his native land, one can not forget that he was, above all, a teacher, a research teacher who perfectly understood the importance of education for the better future of his people. He emphasized that our people through enlightenment will rise from a deep sleep, rise to a better material life and thereby provide a better future. Having written about the conceptual and methodological foundations of the philosophy of education, A. Voloshin largely outstripped his contemporaries, and this is the real greatness of this man who gave more than 45 years of his creative life to pedagogical and cultural-educational work. Pedagogical heritage, scientific, universal, philosophical views of the prominent Ukrainian scientist are still waiting for their researchers.

Keywords: Augustin Voloshyn, pedagogical, scientific, methodological, Transcarpathian Ukraine.

Formulation of the problem. Nowadays significant socio-political and cultural transformations determine the axiological problems of pedagogical science as priorities for modern Ukrainian society. The ancient questions "Where are we from?", "Who are we?", "Where are we going?" are getting clear contours now, are being filled with specific content, value orientations, among which there are the following concepts and phenomena: "nation", "people", "patriotism", "statehood", "public", - constants, formulated in the Constitution of Ukraine and special laws about education. That is why, at the time when Ukraine is confidently stepping into the world community, every conscious citizen, the patriot feels responsible for her future, for the contribution of the spiritual values of the Ukrainian people to the national, regional and world culture. A special role in this process belongs to the bright personalities, scientists-researchers, who, due to their scientific and creative achievements, raise the prestige of the state in the world. Augustin Ivanovych Voloshyn, President of Carpathian Ukraine in 1939, belongs to outstanding personalities with rich life experience, original philosophical and psychological-pedagogical thinking, significant scientific achievements in favor of political, economic, cultural, national and religious development of Transcarpathia. It has been more than 140 years since the birth of the prominent Ukrainian scientist A. Voloshyn, but today, unfortunately, the name of this versatile gifted personality is little known to the general public.

Analysis of recent researches. Despite the fact that A. Voloshyn was a talented person not only in the questions concerning philosophy of education, but also in many other fields, it is useless to look for this name in encyclopaedic editions. There have been done researches about his creative activity by A. Stefan, P. Sterch, V. Birchak, V Zadorozhny, M. Vegesh, B. Galas, V. Gomonnay, M. Zimomrya, M. Klyap, M. Yevtukh, T. Bednarzhova, V. Kemin, O. Dovhanich, P. Fedak and others. At the same time, his legacy is the result of spiritual competitions in various aspects of the material and cultural spheres remains little studied and interpreted, but it is absolutely necessary today for public and especially for young people for adequate knowledge of Ukrainian history, in particular historical events that took place in Transcarpathia before the Second World War.

Research goal and objectives. The goal is to study the principles of the philosophy of education by A. Voloshyn, and the objectives are to highlight his main pedagogical ideas, to reveal his role in the development of public education in Transcarpathia in the 1920s-1930s, to trace qualitative changes in the system of education, to prepare pedagogical staff, to approve the Ukrainian national idea in Transcarpathia, to consider main biographical data of this outstanding personality.

Study presentation. Augustin Ivanovych Voloshyn was born on March 17, 1874 in the village Kelechini in Volivsky district (now Mezhygirsky district) in Transcarpathia in family of village priest. He finished gymnasium in Uzhhorod, and in 1896 he graduated from the Faculty of Theology of Uzhgorod University. Working as a priest he graduated from the Higher Pedagogical School in Budapest in 1900 and became a teacher in Uzhhorod Teachers' Seminary, and later he was the director of this institution more than 20 years. He published more than 40 books, mostly textbooks for schools, which brought up several generations in Transcarpathia, founded and published the newspaper "Science" and "The Village", a series of cheap books for people. In 1920 he started publishing monthly religious journal "Evangelist", weekly journal "Ukrainian word" and monthly pedagogical journal "Teacher's voice." A. Voloshyn's legacy also includes poems, stories, novels, plays.

The integrity of $A$. Voloshyn's personality is determined by not only the research and pedagogical components, but also by his encyclopedic knowledge of classical philosophy, European pedagogy and psychology in XIX - early XX century. He worked hard learning works of prominent scholars: Y. Komensky, J. Pestalozzi, J. Gerbart, J. Locke, J.-J. Russo, Voltaire, G. Spencer, J. Fichte, G. Hegel, K. Ushinsky, T. Shevchenko, I. Franko and many others. Doing educational researches, he relied on the achievements in teaching and psychology, wanted to continue the best traditions of Transcarpathian pedagogical school namely traditions by O. Duhnovich, 
I. Silvaya, J. Rakowski, A. Mytraka and others. A. Voloshyn was interested in the concept of O. Dukhnovich. Like O. Dukhnovich, he focused on the development of public education, the preparation of textbooks for public schools. A. Voloshyn was a talented teacher himself and the director of Uzhgorod Teachers' Seminary from 1916 to 1938 , and headed the work of the Pedagogical Society of Subcarpathian Rus.

A. Voloshyn was the initiator and founder of the Ukrainian Christian-People's Party, which he had headed for a long time. This party gradually attracted the best representatives of the Ukrainian national camp, fought for the rights of Ukrainians. In October 1938, Ukrainians, taking advantage of the political situation in Czechoslovakia, achieved the status of an autonomous province for the Ukrainian Transcarpathia - Subcarpathian Rus. The first government, which was mostly Hungarian, lasted for a short time. Formation of the new government was entrusted to A. Voloshyn.

For the political consolidation of Transcarpathia in January 1939, a unified political structure was created - the Ukrainian National Community, which won the vast majority of seats in the Sejm elections. The armed forces "Carpathian Sich" began to appear in the region with the help of prominent figures of the Organization of Ukrainian Nationalists. In March 1939, the New Sejm unanimously elected A. Voloshyn as President of the Carpathian Ukraine, approved the Constitution, national symbols - the blue-yellow flag, the anthem "Ukraine is still not dead" and the regional emblem, the constituent part of which was the golden trident. But very soon overcoming the resistance of the soldiers of the Carpathian Sich, the Hungarian troops occupied Transcarpathia. A. Voloshyn was forced to leave his native land. He lived in Prague, continued his pedagogical activity, became a professor at the Ukrainian Free University, his rector.

A. Voloshyn's great achievement in the field of education is that he initiated the creation of a very active public organization of teachers - Pedagogical Society of Subcarpathian Rus in the early 1920s. Having discussed all the important organizational issues with his supporters, he convened a meeting of representatives of pedagogical collectives, where the formation of Pedagogical Society of Subcarpathian Rus was proclaimed on October 4, 1924. The Chairman of the Society was elected A. Voloshyn and he had been the leader until 1937. Despite being very busy A. Voloshyn paid much attention to the activities of the Society.

Headed by A. Voloshyn, Pedagogical Society of Subcarpathian Rus published a monthly magazine "Subcarpathian Rus". For a long time A. Voloshyn was the editor-in-chief of the magazine and wanted to make it for all educators in the region. It printed the basic acts about education, articles on the history of school and pedagogy, the experience of teachers etc. The best pedagogical works by A. Voloshyn appeared on the pages of "Subcarpathian Rus". This magazine had become the platform for the exchange of advanced pedagogical experience for teachers in Transcarpathia.

In 1929, the progressive organization "Teacher's Community" was established, whose honorary head had been A. Voloshyn until 1939. The community held a large organizational work among teachers (theme evenings, conferences), published literature, which contributed to the growth of their qualifications. The organization published the magazines "Teacher's Voice" and "Our School".

A number of important works about the problems of pedagogy A. Voloshyn published on the pages of the Scientific collection of the Society "Enlightenment in Uzhgorod" (1922-1938). Work about the history of pedagogy and struggle to preserve the mother tongue $[4 ; 7 ; 9]$ deserves particular attention. Taking care of the training of pedagogical staff for Transcarpathian schools, A. Voloshyn was aware of the need for radical changes in the school system. He devoted the work "Democratic School Reform (to the question of modernization of school laws)" (1928) to this problem. The scientist substantiated some of the main principles of building a democratic school in this book. Pointing out the urgency of the problem, he stressed that it was a requirement of time, because "the advancement of culture freedom develops the idea of democratization of the school system" [1, 184]. The author singled out six main stages of the development of the school system: from ancient times through the monopoly of the church and state to the school up to full democratization of the school system. One of the main factors of the latter should be "the principle that a child with a mother's word should receive science and no one can compel to bring the child to school for other nation or religion" [1, 184].

The author gave a historical overview of the development of the school system, pointing to the main varieties of schools (rural, church, state, private), characterizing the reactionary, chauvinistic legislation of the Austro-Hungarian school. A. Voloshyn payed special attention to two extremes - communism and fascism, which are harmful to culture and hinder the progress of schooling.

According to A. Voloshyn, only the principle of culture freedom can be fundamental for the progress of the school system. He calls for an assessment of school reform "from such points of view: 1) pedagogical, 2) cultural-historical, and 3) economic" [1, 186], but not political. In fact, A. Voloshyn laid the foundations for the principles of a new pedagogical thinking, which synthesized the principles and methods of teaching as a harmonious system of education that maximally approximated the process of learning and upbringing, combining moral, spiritual, and labor upbringing.

The foundations of A. Voloshyn's philosophy of education have generalization in the fact that all spiritual and cultural practice of teaching and upbringing is carried out in a substantive social field, where the formation, self-actualization and self-realization of a person take place. As a humanist and philosopher he understood these things and therefore identified five main factors of upbringing: a family, a school, a state, a church and an educator. In addition, A. Voloshyn devoted considerable attention to social upbringing, which is also designed to spread the culture, worldview, bring the light of knowledge and goodness into all spheres of human life [8].

A. Voloshyn managed to notice significant opportunities of folk tools (proverbs, sayings, ethical teachings, tales, legends, parables) and wisely used them in the textbooks. He expressed important thoughts about the humanization of interpersonal relations. Authoritarianism, rudeness, violence against the child nullifies the educational process and loses the child as a person. The scientist-teacher formulated the requirements for the teacher as the main subject of upbringing. According to A. Voloshyn, the teacher is not an actor, but must act as an actor. An indifferent person cannot be a mentor even if he meets all the requirements of didactics. A. Voloshyn wrote: "Only one who has inborn artistic inclinations can become an artist, so a good teacher is born with inclinations, from which the rank and teacher's personality can develop" [2, 34]. This opinion is present in almost all the author's pedagogical writings.

A. Voloshyn considered readiness for a profound analysis of pedagogical phenomena as a necessary element of thorough theoretical and methodological training. But for quality training, the educational process must be provided with the appropriate educational tools. Therefore, A. Voloshyn was one of the first to understand the need for the publication of new textbooks, to develop the structure and content of textbooks for students of the Teachers' Seminary, 
for senior class pupils who wanted to go to the pedagogical work. After prolonged work, he published the first textbooks "The History of Pedagogy for Teachers' Seminary" (1923), "The Brief History of Pedagogy for Teachers' Seminary" (1923), "Pedagogy and Didactics for Teachers' Seminary" (1923), "Pedagogy and Didactics for Teachers' Seminary" (1924), "Pedagogical Psychology" (1930) and others.

The second chapter of the textbook "General Pedagogy", which substantiates the forms and methods of the educational process, is extremely valuable in terms of pedagogy. "Learning means to give new knowledge that become the property of the student's soul. The school provides such a science that serves the purposes of upbringing" $[3,38]$. He convinced that the teacher was able to conduct educational work by means of all subjects, because "the development of the people's spirit must serve... the way of learning" [3, 38].

In the early 1930's A. Voloshyn wrote two more textbooks for pedagogical seminaries - "Didactics" and "General Pedagogy". The author created these new textbooks in order to improve the training of teachers, whose curricula included such subjects as didactics, general pedagogy, and there were no relevant textbooks. As the director of the Teachers' Seminary, he felt the need for such educational tools and wanted to help practitioners.

In these textbooks about pedagogy and didactics, there is much in common, but each of them has its own peculiarities. In "Pedagogy and didactics" (1924), the general principles of the work of the school are described, this textbook has a general information. "Methodology and General Pedagogy" (1932) and "Didactics" (1933), published as manuscripts, deepen some of the important positions of pedagogical theory and practice. Despite some drawbacks, these editions at that time formed the basis for pedagogical teacher training, both in seminaries and in gymnasiums. They were useful to teachers for self-education and advanced training.

A special place in A. Voloshyn's scientific researches belongs to the fundamental work "Methodology of nationalschool education" [6], in which he paid a lot of attention to the questions of improving the educational process, teaching methods of different disciplines. He considered this process as a feedback between the teacher and the students, the family and the school, which, in the opinion of the scientist, greatly increases the positive motivation of education.

Studying the problems of education in the context of his philosophy, developing a methodology of popular-school education, A. Voloshyn attached great importance to the development of curricula and programmes, which made up the content of training, the distribution of material in accordance with school years. The scientist made many efforts to include such subjects as native language, history, arithmetic, geography, religion, labor, singing, drawing, gymnastics in elementary school curricula. He confidently stated that the study of these subjects would undoubtedly contribute to the comprehensive spiritual and physical development of the child in order to socialize a new generation of Ukrainian citizens.

A number of textbooks on pedagogy, psychology and didactics created by A. Voloshyn in the 1920s-1930s became his notable contribution to the training of educators in Transcarpathia. In the first half of the 1940s, the "Pedagogical reader" (40 pages), "Methodology of moral education" (20 pages), "Pedagogical teleology" (15 pages), "Pedagogical psychology" (8 arch.) were finished but not published. "Theory of upbringing" was also prepared for publication. All these works testify to A. Voloshyn's active scientific and pedagogical activity, but they should be found and studied.

A. Voloshyn's philosophy of education included such an important section as the methodology in pedagogical science, therefore, his latest pedagogical work "Pedagogical Methodology" [10], which was published in Prague in 1943, seemed to sum up the conceptualization of scientific and pedagogical search. Here A. Voloshyn outlined how to implement the principles of humanism, spirituality, patriotism, and how to adhere to the doctrine of the principles, methods, forms and processes of knowledge and transformation of pedagogical reality for the present and future generations of educators.

Pedagogical heritage, scientific, universal, philosophical views of the prominent Ukrainian scientist are still waiting for their researchers. Much effort must be made to ensure that A. Voloshyn's spiritual treasure during the era of statehood of Ukraine have become well-known for the Ukrainian people. Their knowledge will certainly help to bring to life the moral and ethical virtues of Christianity, the lack of which is noticeable in modern society.

Reading A. Voloshyn's works, starting with school textbooks, newspapers and ending with scientific-pedagogical researches, you feel their clear patriotic orientation. The essence of the latter was the upbringing a sense of unity with the Ukrainian people in all the social strata of the Carpathian Ukraine, personal responsibility for the fate of Ukraine, readiness for selfless work and struggle for its statehood. The philosophical ideas expressed in his pedagogical works are extremely relevant today, they can well serve the current mentors of children and young people in the practical realization of the objectives of modern pedagogy, defined by the concept of the Ukrainian national school.

Conclusion. The philosophical thought that seems to have been frozen nowadays must prepare for a new universal cognitive effort to look at the horizons of the future and take over the mission of comprehension and rethinking of the national and universal (historical, political, socio-psychological, philosophical and pedagogical etc.) of the experience. In this context, philosophical and philosophical-pedagogical legacy by A. Voloshyn as a prominent Ukrainian thinker, humanist, enlightener has an important role.

This year in July there will be 73 years since Augustine Voloshyn's death in the Soviet prison. He was a man who, according his views, belonged to the intellectual elite not only Transcarpathia, but also of the whole Europe. His contribution to the all-Ukrainian national liberation movement cannot be overestimated. Remembering A. Voloshyn's merits, as a politician, a fighter for freedom and independence of his native land, one must not forget that he was primarily a teacher, a pedagogue-researcher, who perfectly understood the importance of education for the better future of his people. He emphasized that "our people through enlightenment will rise from a deep sleep, rise to a better material life and thus provide a better future" $[11,136]$. Writing about conceptual and methodological foundations of the philosophy of education, A. Voloshyn largely went ahead of his contemporaries, and this is the true grandeur of this man who gave more than 45 years of his creative life to pedagogical and cultural-educational work.

\section{References}

1. Voloshyn A. Demokratychna shkilna reforma (do pytannia novelizatsii shkilnykh zakoniv) // Pidkarpatska Rus. - Uzhhorod, 1928. - R. 5. - № 8-9. S. 181-186.

2. Voloshyn A. Dydaktyka. - Uzhhorod : Vydannia nakladom Pedahohichnoho tovarystva Pidkarpatskoi Rusi, 1933 - $91 \mathrm{~s}$

3. Voloshyn A. Zahalna pedahohika. - Uzhhorod : Vydannia nakladom Pedahohichnoho tovarystva Pidkarpatskoi Rusi, 1932. - $104 \mathrm{~s}$

4. Voloshyn A. Istoriia pedahohiky dlia uchytelskykh seminarii. - Uzhhorod: Unio, 1923. - $109 \mathrm{~s}$.

5. Voloshyn A. Metodyka. - Uzhhorod : Vydannia nakladom Pedahohichnoho tovarystva Pidkarpatskoi Rusi, 1932. - $99 \mathrm{~s}$.

6. Voloshyn A. Metodyka narodno-shkilnoho navchannia. - Uzhhorod: Vydannia nakladom Pedahohichnoho tovarystva Pidkarpatskoi Rusi, 1935. - 84 s. 
7. Voloshyn A. Oborona Kyrylyky : Yak oboronialysia pidkarpatski rusyny proty ostannoho aktu madiaryzatsii pered perevorotom? // Naukovyi zbirnyk Tovarystva "Prosvita". - Uzhhorod, 1937. - T.12. - S.87 - 117

8. Voloshyn A. O sotsiialnom vykhovanniu. - Uzhhorod : Unio, 1924. - $46 \mathrm{~s}$.

9. Voloshyn A. Pedahohika i dydaktyka. - Uzhhorod : Unio, 1924. - $80 \mathrm{~s}$

10. Voloshyn A. Pedahohichna metodolohiia. Kn.1. Metodolohiia navchannia : Dlia vchyteliv ta vchytelskykh seminarii. - Praha: Ukrainske vydavnytstvo "Proboiem", 1943. - $208 \mathrm{~s}$

11. Voloshyn A. Perehliad istorii shkilnytstva Pidkarpatskoi Rusi // Tvory. Uzhhorod : Vydannia nakladom Pedahohichnoho tovarystva Pidkarpatskoi Rusi, 1937. - S.128-136.

Список використаних джерел

1. Волошин А. Демократична шкільна реформа (до питання новелізації шкільних законів) / А. Волошин // Підкарпатська Русь. - Ужгород, 1928 - Вип. 5. - № 8-9 - С. 181-186.

2. Волошин А. Дидактика / А. Волошин. -Ужгород : видання накладом Педагогічного товариства Підкарпатської Русі, 1933. - 91 с.

3. Волошин А. Загальна педагогіка / А. Волошин - Ужгород : видання накладом Педагогіч-ного товариства Підкарпатської Русі, 1932. Вип. 104. - С. 44
4. Волошин А. Історія педагогіки для учительських семінарій / А. Волошин. - Ужгород : Уніо, 1923. - 109 с.

5. Волошин А. Методика / А. Волошин. - Ужгород : видання накладом Педагогічного това-риства Підкарпатської Русі, 1932. - 99 с.

6. Волошин А. Методика народно-шкільного навчання / А. Волошин. Ужгород: Видання накладом Педагогічного товариства Підкарпатської Русі, 1935. - 84 с.

7. Волошин А. Оборона Кирилики: як оборонялися підкарпатські русини проти останнього акту мадяризації перед переворотом? / А. Волошин // наук. зб. тов-ва "Просвіта". - Ужгород, 1937. - Т. 12. - С. 87-117.

8. Волошин А. О соціяльном вихованню / А. Волошин. - Ужгород : Уніо, 1924. $-46 \mathrm{c}$.

9. Волошин А. Педагогіка і дидактика / А. Волошин. - Ужгород : Уніо, 1924. $-80 \mathrm{c}$.

10. Волошин А. Педагогічна методологія. Кн.1. Методологія навчання : Пля вчителів та вчительських семінарій / А. Волошин. - Прага :Укр. видво "Пробоєм", 1943. - 208 с.

11. Волошин А. Перегляд історії шкільництва Підкарпатської Русі : твори / А. Волошин. - Ужгород : вид-ня накладом Педагогічного тов-ва Підкарпатської Русі, 1937. - С. 128-136.

Надійшла до редколегії 27.01.19

Х. Бахтіярова, канд. пед. наук, доц., проф.

Національний транспортний університет, Київ, Україна

\section{АВГУСТИН ВОЛОШИН ЯК ПРОВІСНИК ФІЛОСОФСЬКО-ПЕДАГОГІЧНОЇ ДУМКИ НА ЗЛАМІ ЕПОХ}

Розглянуто життєвий шлях Августина Волошина, охарактеризовано викладацьку, науково-організаційну, видавничу та політичну діяльність, проаналізовано його філософсько-педагогічну концепцію, яка зробила вагомий внесок у методичне та дидактичне забезпечення розбудови освіти в Закарпатській Україні. Філософська думка, яка, як здається, застигла в даний час, має підготуватися до нового універсального пізнавального прагнення подивитися на горизонти майбутнього і взяти на себе місію розуміння та переосмислення національного й універсального (історичного, політичного, соціально-психологічного, філософського) педагогічного досвіду. Контатовано важливу роль філософсько-педагогічну спадщину А. Волошина як видатного українського мислителя, гуманіста, просвітителя. Особливе місце у наукових пошуках А. Волошина належить фундаментальній праці "Методика народно-шкільного навчання", у якій він багато уваги приділив питанням удосконалення навчального процесу, методиці викладання окремих дисциплін. Він уявляв цей процес як зворотний зв'язок між учителем та учнями, родиною та школою, що, на думку вченого, значно підвищує позитивну мотивацію навчання. Зәадуючи заслуги А. Волошина як політика, борця за свободу і незалежність рідної землі, не можна забувати, що він був насамперед вчителем, педагогом-дослідником, який чудово розумів важливість освіти для кращого майбутнього свого народу. Він зазначив, що наш народ через просвітлення підніметься з глибокого сну, підніметься до кращого матеріального життя і тим самим забезпечить краще майбутнє. Написавши про концептуальні та методологічні основи фрілософії освіти, А. Волошин значною мірою випередив своїх сучасників, і це справжня велич цієї людини, що віддав більще 45 років свого творчого життя педагогічній і культурно-просвітницькій роботі. Педагогічна спадщина, наукові, універсальні, філософські погляди видатного українського вченого все ще чекають своїх дослідників. Необхідно докласти багато зусиль для того, щоб духовний скарб А. Волошина в епоху державності України став відомим для українського народу.

Ключові слова: Августин Волошин, філософсько-педагогічна думка, народна освіта, педагогічне мислення.

UDC 371

N. Demyanenko, Dr. of Pedagogical Sci., Prof. National Pedagogical University named after M.P. Drahomanov, Kyiv, Ukraine

\section{IMPLEMENTATION OF AUTHOR CONCEPT OF I. O. SIKORSKY IN THE ACTIVITIES OF THE KIEV FROEBEL PEDAGOGICAL INSTITUTE (1907-1920)}

The article carries out a retrospective logical-system analysis of the scientific heritage of the first rector of the Kiev Froebel Pedagogical Institute l.O. Sikorsky (1842-1919) - a doctor of medicine, a well-known teacher and psychologist, a professor of the University of St. Volodymyr, chairman of the Kiev Froebel Society of the Promotion of Education. It was found out that the scientist considered the comprehensive knowledge of the child by a chain that unites family and school, and the integration of knowledge on psychology, medicine, upbringing and development of the family was a foundation for effective education of the individual. The interpretation of the ultimate goal of education by I.O. Sikorsky defined as the achievement of harmonious development of the spirit and body, mental and physical, as the balance of mental, moral and aesthetic principles. The directions and mechanisms of implementation of the author's medical-psychological-pedagogical concept I.O. Sikorsky are investigated in the content of vocational and pedagogical training of the Kiev Froebel Pedagogical Institute (1907-1920).

Keywords: I. Sikorsky, author's concept, Kiev Froebel Pedagogical Institute, retrospective, education, personality, professional pedagogical training.

Formulation of the problem. Ukraine has a valuable historical experience in setting up the institutions of higher education, the effectiveness of which has been tested by time. The Kiev Froebel Pedagogical Institute (1907-1920) is considered unique in terms of meaning, content and forms of activity. I.O. Sikorsky was its first and long time unchanged rector, a doctor of medicine, a well-known psychologist, a teacher, a professor at the University of St. Volodymyr, chairman of the Kiev Froebel Society of the Promotion of Education. His author medical-psychological-pedagogical concept, in coordination with the pedagogical system of the famous German educator F. Froebel, became the basis for the training of European-level pedagogical staff.

Study presentation. Ivan Sikorsky was born in the Antonove village of Skvirsky district of Kiev province in May 24, 1842. He gained primary education in theological school, continued studying in the seminary. In 1862 he externally passed the exam at the Kiev First Gymnasium and entered the University of St. Volodymyr. After listening to two courses in the natural department, he moved to the medical faculty, which graduated in 1869. In 1872 he defended his thesis for a doctor of medicine. In the same year he moved 